\title{
Correction to: Interagency Relations and the EU Migration Crisis: Strengthening of Law Enforcement Through Agencification?
}

Chiara Loschi and Peter Slominski

Correction to:

Chapter 9 in: J. Pollak and P. Slominski (eds.), The Role of EU Agencies in the Eurozone and Migration Crisis, European Administrative Governance, https://doi.org/10.1007/978-3-030-51383-2_9

The Chapter 9 "Interagency Relations and the EU Migration Crisis: Strengthening of Law Enforcement Through Agencification?" was previously published non-open access. It has now been changed to open access under a CC BY 4.0 license and the copyright holder updated to 'The Author(s)'. The book has also been updated with this changes

The updated version of this chapter can be found at https://doi.org/10.1007/978-3-030-51383-2_9

(C) The Author(s) 2021

$\mathrm{Cl}$

J. Pollak and P. Slominski (eds.), The Role of EU Agencies in the Eurozone and Migration Crisis, European Administrative Governance, https://doi.org/10.1007/978-3-030-51383-2_10 